\title{
Pengaruh Model Pembelajaran (Problem Based Learning dan Konvensional) Terhadap Keterampilan Proses Sains dan Hasil Belajar Siswa Sekolah Menengah Pertama
}

\author{
Lusndico Saragih \\ Program Studi Pendidikan Biologi Pascasarjana, Universitas Negeri Medan, Sumatera Utara, Indonesia
}

\begin{abstract}
Abstrak: Penelitian ini dilakukan pada siswa SMP Swasta Silinda yang bertujuan untuk mengetahui pengaruh model pembelajaran (problem based learning, dan konvensional) terhadap: (1) keterampilan proses sains; dan (2) hasil belajar siswapada materi ekosistem. Sampel penelitian ini merupakan populasi total siswa kelas VII SMP Swasta Silinda Semester Genap Tahun Pembelajaran 2015/2016 berjumlah 60 siswa yang terbagi kedalam 2 kelas, dimana masing-masing kelas terdapat 30 siswa.Instrumen dalam penelitian ini berupates hasil belajar siswa, dan observasi keterampilan proses sains siswa. Metode penelitian ini bersifat kuasi eksperimen (quasi eksperimental method) dengan teknik analisis hipotesis uji tpada taraf signifikansi $\alpha=0,05$. Hasil penelitian ini diperoleh bahwa:(1)terdapat pengaruh model pembelajaran (Problem Based Learning, dan konvensional) terhadap keterampilan proses sains siswa pada materi ekosistemSMP Swasta Silinda Serdang Bedagai $\left(\mathrm{t}_{\text {hitung }}=\right.$ 5,424; P = 0,000); dan (2) terdapat pengaruh model pembelajaran (Problem Based Learning, dan konvensional) terhadap hasil belajar siswa pada materi ekosistemSMP Swasta Silinda Serdang Bedagai $\left(\mathrm{t}_{\mathrm{hitung}}=3,342 ; \mathrm{P}=\right.$ 0,001). Hasil penelitan ini mengimplikasikan bahwamodel pembelajaran problem based learningmemberikan dampak untuk mengembangkanketerampilan proses sains dan meningkatkan hasil belajar siswa menjadi lebih baik.
\end{abstract}

Kata Kunci: Model Pembelajaran, Problem Based Learning, Keterampilan Proses Sains, Hasil Belajar Siswa

\section{PENDAHULUAN}

Belajar merupakan proses yang kompleks yang terjadi pada setiap orang disepanjang hidupnya. Dalam proses belajar melibatkan adanya interaksi antara seseorang dengan lingkungan sekitarnya. Oleh karena itu, belajar dapat terjadi kapan saja dan dimana saja. Salah satu pertanda seseorang itu telah mengalami belajar adalah adanya perubahan tingkah laku pada diri seseorang yang disebabkan oleh terjadinya perubahan pada tingkat pengetahuan, keterampilan, atau sikapnya (Arsyad, 2007). Maka proses dalam belajar merupakan peristiwa penting dalam memberikan penyampaian materi pelajaran kepada para siswa dengan cara yang baik dan tepat yang disebut dengan proses pembelajaran.

Proses pembelajaran yang selama ini diselenggarakan di sekolah, tidak lain bertujuan untuk mengarahkan perubahan tingkah laku siswa secara sederhana, baik dalam aspek pengetahuan, keterampilan, maupun sikap. Sebagaimana dikemukakan oleh Hamalik (2008) menyatakan bahwa belajar adalah proses kegiatan belajar mengajar, dimana dalam proses tersebut merupakan proses penyampaian pengetahuan yang akan diberikan kepada siswa dengan baik, benar dan tepat sesuai dengan tujuan pembelajaran yang diinginkan, bukan hanya sekedar mencapai suatu hasil atau tujuannya saja. Namun dalam dunia pendidikan di Indonesia tujuan merupakan faktor prioritas yang ingin dicapai tanpa melihat suatu proses bagaimana penyampaian pengetahuan itu dapat diterima oleh para peserta didik di sekolah. Proses pembelajaran merupakan faktor yang sangat penting untuk diketahui bagaimana siswa memperoleh pengetahuannya khususnya mata pelajaran Ilmu Pengetahuan Alam (IPA) di dalam kelas. Karena belajar bukan hanya untuk mengingat akan apa yang telah terjadi tetapi belajar mengandung makna yang lebih luas yakni mengalami proses belajar itu sendiri. Oleh sebab itu, pembelajaran adalah proses interaksi peserta didik dengan pendidik dan sumber belajar pada suatu lingkungan belajar.Pembelajaran yang dimaksud adalah pembelajaran yang berkualitas sangat tergantung dari motivasi pelajar dan kreatifitas pengajar untuk mencapai keberhasilan pencapaian target belajar (Dimyati dan Mudjiono, 1999). Maka peran guru memliki peranan penting dalam menyampaikan pengetahuan berupa materi IPA kepada para siswa dengan baik dan benar serta dengan proses pembelajaran yang tepat pula.

Oleh karena itu peran guru tidak hanya sekedar mengajar melainkan membelajarkan peserta didik agar mau belajar. Tugas guru dalam proses pembelajaran, disamping menyampaikan informasi, ia juga bertugas 
mendiagnosis kesulitan belajar siswa, menyeleksi materi ajar, mensupervisi kegiatan belajar, menstimulasi kegiatan belajar siswa, memberikan bimbingan belajar, mengembangkan dan menggunakan model dan metode (Arends, 2008). Akan tetapi pembelajaran pada saat ini masih berorientasi kepada guru (teacher oriented), sehingga hal ini memberikan dampak kepada para siswa kurang untuk diberi kesempatan dalam menyelesaikan suatu bentuk permasalahan materi pembelajaran ketika proses pembelajaran berlangsung yang berdampak pula pada rendahnya motivasi belajar siswa dan minat belajar siswa karena ketika pada proses pembelajaran tersebut siswa kurang dapat dengan bebas dalam mengembangkan kemampuan berpikirnya di dalam kelas. Proses yang demikian ini juga terjadi pada SMP Swasta Silinda Serdang Bedagai. Sebagaimana hasil studi pendahuluan melalui wawancara peneliti di sekolah diperoleh bahwa dalam proses pembelajaran IPA masih berlangsung dengan proses pembelajaran konvensional, yakni masih menggunakan proses ceramah dan tanya jawab, sehingga materi pembelajaran beberapa diantaranya masih belum dikontekskan dengan kehidupan nyata siswa yang menyebabkan siswa sulit untuk menganalisis, menyimpulkan dan mengevaluasi hasil dari manfaat proses pembelajaran yang telah dilakukan di dalam kelas. Hal ini memberikan rendahnya minat dan motivasi belajar siswa di dalam kelas.

Maka berdasarkan uraian tersebut, perlu adanya suatu penelitian yang bertujuan untuk membangun motivasi siswa dan mendukung cara siswa dalam menyelesaikan proses pembelajarannya kearah yang lebih baik kedepannya. Salah satu proses pembelajaran yang mendorong siswa agar mampu menyelesaikan suatu permasalahan pembelajaran serta melatih kemampuan berpikir siswa dalam menyelasaikan masalah dari materi IPA dan meningkatkan motivasi belajar siswa, yakni model pembelajaran berbasis masalah (problem based learning).

Model pembelajaran berbasis masalah (problem based learning) merupakan model pembelajaran didalam kelas dalam bentuk penyelidikan dan penuntasan masalah kehidupan nyata (Arends, 2008). Maksud dari mengatasi masalah ini ialah merancang suatu penelitian dengan menggunakan model pembelajaran yang lebih tepat. Sehingga model pembelajaran ini diharapkan dapat meningkatkan kemampuan berpikir dan motivasi belajar siswa. Model pembelajaran ini tidak hanya berpusat guru melainkan juga kepada para siswa dengan membangkitkan diskusi dalam proses pembelajarannya dan hasil belajar siswa menjadi lebih baik (Cinar, 2007). Sebagaimana dikemukakan oleh Bangun (2012) tujuan model problem based learning adalah untuk mencapai pembelajaran yang efektif dalam mengembangkan pengetahuan, pemahaman dan kemampuan berpikir siswa untuk memecahkan masalah. Dalam model problem based learning siswa akan terlibat secara langsung dan akan membuat siswa lebih memahami dan lebih banyak mengingat materi pelajaran IPA menjadi lebih baik.

Oleh sebab itu diperlukan suatu model pembelajaran yang mampu meningkatkan kemampuan siswa dalam menyelesaikan masalah IPA dan juga memampukan siswa untuk memunculkan ide/gagasan sehingga siswa menjadi lebih aktif dan termotivasi dalam belajar. Model problem based learning dianggap mampu membantu siswa memecahkan suatu permasalahan dengan cara bekerja sama satu dengan yang lain maupun berkelompok diskusi belajarnya.Sehingga dengan menggunakan model pembelajaran berdasarkan masalah dapat membantu siswa menyelesaikan suatu permasalahan IPA dengan kerjasama, sehingga dapat memotivasi siswa untuk dapat belajar aktif dan siswa merasa tidak sendirian dalam mengerjakan masalah tersebut. Dengan kondisi seperti ini diharapkan dapat menciptakan suasana belajar yang bermakna dan menyenangkan sehingga siswa lebih memahami konsep IPA tersebut.

Pembelajaran biologi di SMP menekankan pada kemampuan aktivitas siswa dan keterampilan proses sains. Keterampilan proses sains bagi siswa SMP diarahkan pada keterampilan proses sains terpadu sebagai pengembangan keterampilan proses sains dasar. Pemberdayaan siswa dalam pengembangan keterampilan proses sains akan membentuk karakter siswa dengan sikap ilmiah, kemampuan berpikir dan bertindak kritis baik selama pembelajaran maupun dalam konteks kehidupan sehari-hari. Namum sampai sekarang pembelajaran dengan pendekatan keterampilan proses sangat jarang dilakukandi dalam kelas pada pembelajaran biologi karena masih kurangnya kreatif guru dalam menerapkan keterampilanproses pada proses pembelajaran IPA di dalam kelas.

Beberapa strategi yang lazim dilakukan dalam mengembangkan kemampuan aktivitas siswa adalah dengan pendekatan keterampilan proses sains. Keterampilan proses sains bagi 
siswa diarahkan pada keterampilan proses sains terpadu sebagai pengembangan keterampilan proses sains. Pemberdayaan siswa dalam pengembangan keterampilan proses sains akan membentuk karakter siswa dengan sikap ilmiah, kemampuan berpikir dan bertindak kritis baik selama pembelajaran maupun dalam konteks kehidupan sehari-hari.

Sebagaimana hasil penelitian yang dikemukakan oleh Ango (2002) bahwa keterampilan proses memiliki peranan yang sangat penting untuk pengembangan pemahaman oleh siswa dalam menerapkan konsep ilmiah dan meningkatkan proposisi belajarnya. Sehingga melalui pengalamanpengalaman dalam pembelajaran keterampilan proses, siswa dapat mencapai keahlian dalam pembelajaran yang bermakna dalam prosedur pemecahan masalah secara ilmiah dan menerapkan pemahamanilmiah tersebut dalam kehidupan mereka sendiri.

Karamustafaoglu (2011) mengemukakan bahwa ilmu keterampilan proses memberikan manfaat meningkatkan hasil belajar peserta didik serta partisipasi peserta didik di dalam kegiatan laboratorium sains, dimana ilmu keterampilan proses tidak dapat dipisahkan dalam praktek dari konseptual pemahaman yang terlibat dalam belajar dan menerapkan ilmu pengetahuan. Dengan demikian pendekatan keterampilan proses melibatkan keterampilan-keterampilan kognitif atau intelektual, manual, dan sosial peserta didik dengan menggunakan pikirannyaserta menanamkan sikap ilmiah peserta didik pada pembelajaran IPA dalam meningkatkan hasil belajar yang lebih baik lagi. Berdasarkan uraian diatas, peneliti terdorong untuk melakukan penelitian dengan judul: Pengaruh Model Pembelajaran (Problem Based Learning, dan Konvensional) Terhadap Keterampilan Proses dan Hasil Belajar Siswa pada Materi EkosistemSMP Swasta Silinda Serdang Bedagai.

\section{METODE PENELITIAN}

Penelitian ini dilaksanakan di SMP Swasta Silinda yang beralamat di Jalan Besar Gunung Meriah, Desa Silinda Kabupaten Serdang Bedagai. Penelitian ini direncanakan dilaksanakan pada bulan Januari sampai dengan Mei 2016.Populasi penelitian ini adalah seluruh siswa kelas VII SMP Swasta Silinda Semester Genap Tahun Pembelajaran 2015/2016 yang berjumlah 60 siswa yang terbagi kedalam 2 kelas, dimana masing-masing kelas terdapat 30 siswa.Sampel penelitian ini merupakan sampel dari populasi total siswa kelas VII SMP Swasta Silinda Semester Genap Tahun Pembelajaran 2015/2016 yang masing-masing sekolah memiliki 2 kelas, yaitu kelas pertama menggunakan model pembelajaran berbasis masalah (problem based learning), kelas kedua menggunakan pembelajaran konvensional sebagai kelas kontrol (pengendali).Variabel bebas dalam penelitian ini adalah pembelajaran dengan menggunakan model pembelajaran pembelajaran berbasis masalah (problem based learning), dan pembelajaran konvensional. Variabel terikat pada penelitian ini adalah keterampilan proses dan hasil belajar kognitif siswa.Penelitian ini termasuk jenis penelitian kuasi eksperimen, dengan desain penelitiannya berupa Two Group Pretest-Postest Design.

\section{Teknik Pengumpulan Data}

Teknik pengumpulan data pada penelitian ini berupa tes dan lembar observasi keterampilan proses sains siswa. Untuk tes hasil belajar siswa yang disusun peneliti dalam bentuk pilihan berganda dengan lima pilihan yang berjumlah 40 soal. Sedangkan Keterampilan Proses Sains (KPS)observasi berjumlah 8 soal dengan bobot skor pernyataan jika sangat baik bernilai 4, baik bernilai 3, sedang bernilai 2 , tidak baik bernilai 1 . Sehingga skor minimum adalah 8, dan skor maksimum adalah 32 .

\section{Teknik Analisis Data}

Teknik analisis data yang digunakan dalam penelitian ini meliputi analisis inferensial parametrik. Sebelum data hasil penelitian dianalisis, perlu dilakukan uji persyaratan yang meliputi: uji normalitas (Kolmogorov Smirnov test)dan uji homogenitas(Levene's test).Teknik analisis data inferensial digunakan untuk menguji hipotesis penelitian dengan menggunakan uji t pada taraf signifikan $\alpha=$ 0,05.Data dianalisis dengan menggunakan software SPSS 17.0. 


\section{HASIL PENELITIAN}

\section{Pretest Siswa}

Deskripsi Pretes Siswa disajikan pada Tabel 1.

Tabel 1. Deskripsi Pretes Siswa

\begin{tabular}{llcccc}
\hline No. & Model Pembelajaran & $\begin{array}{c}\text { Rata-rata Pretes } \\
\text { Siswa }\end{array}$ & $\begin{array}{c}\text { Nilai } \\
\text { Minimum }\end{array}$ & $\begin{array}{c}\text { Nilai } \\
\text { Maksimum }\end{array}$ & $\begin{array}{c}\text { Standard } \\
\text { Deviasi }\end{array}$ \\
\hline 1. & Problem Based Learning & 48,41 & 30,00 & 62,50 & 8,47 \\
2. & Konvensional & 48,75 & 32,50 & 75,00 & 9,84 \\
\hline
\end{tabular}

\section{Deskripsi Postes (Hasil Belajar) Siswa}

Deskripsi Hasil Belajar Siswa disajikan pada Tabel 2.

Tabel 2. Deskripsi Hasil Belajar Siswa

\begin{tabular}{clcccc}
\hline No. & Model Pembelajaran & $\begin{array}{c}\text { Rata-rata Hasil } \\
\text { Belajar Siswa }\end{array}$ & $\begin{array}{c}\text { Nilai } \\
\text { Minimum }\end{array}$ & $\begin{array}{c}\text { Nilai } \\
\text { Maksimum }\end{array}$ & $\begin{array}{c}\text { Standard } \\
\text { Deviasi }\end{array}$ \\
\hline 1. & Problem Based Learning & 74,25 & 62,50 & 82,50 & 5,87 \\
2. & Konvensional & 67,66 & 50,00 & 82,50 & 9,04 \\
\hline
\end{tabular}

\section{Deskripsi PretesKeterampilan Proses Sains Siswa}

Deskripsi Pretes Keterampilan Proses Sains Siswa disajikan pada Tabel 3.

Tabel 3. Deskripsi Pretes Keterampilan Proses Sains Siswa

\begin{tabular}{clcccc}
\hline No. & Model Pembelajaran & Rata-rata Nilai Pretes & $\begin{array}{c}\text { Nilai } \\
\text { Minimum }\end{array}$ & $\begin{array}{c}\text { Nilai } \\
\text { Maksimum }\end{array}$ & $\begin{array}{c}\text { Standard } \\
\text { Deviasi }\end{array}$ \\
\hline 1. & Problem Based Learning & 42,08 & 25,00 & 62,50 & 9,16 \\
2. & Konvensional & 40,41 & 25,00 & 56,25 & 9,38 \\
\hline
\end{tabular}

Deskripsi Postes Keterampilan Proses Sains Siswa

Deskripsi Postes Keterampilan Proses Sains Siswa disajikan pada Tabel 4.

Tabel 4. Deskripsi Postes Keterampilan Proses Sains Siswa

\begin{tabular}{clcccc}
\hline No. & Model Pembelajaran & Rata-rata Nilai Postes & $\begin{array}{c}\text { Nilai } \\
\text { Minimum }\end{array}$ & $\begin{array}{c}\text { Nilai } \\
\text { Maksimum }\end{array}$ & $\begin{array}{c}\text { Standard } \\
\text { Deviasi }\end{array}$ \\
\hline 1. & Problem Based Learning & 64,27 & 53,13 & 87,50 & 7,46 \\
2. & Konvensional & 54,37 & 40,63 & 68,75 & 6,64 \\
\hline
\end{tabular}

Pengaruh Model Pembelajaran (Problem Based Learning, dan Konvensional) Terhadap Keterampilan Proses Sains Siswa Sekolah Menengah Pertama

Berdasarkan hasil uji hipotesis diperoleh bahwa terdapat pengaruh model pembelajaran (Problem Based Learning, dan konvensional) terhadap keterampilan prosessains siswa pada materi ekosistem SMP Swasta Silinda Serdang Bedagai ( $\mathrm{t}_{\text {hitung }}=5,424 ; \mathrm{P}=0,000$ ). Hal ini dapat dilihat pada keterampilan proses sains siswa pada materi ekosistem yang dibelajarkan dengan model pembelajaran Problem Based Learning $(64,27 \pm 7,46)$ signifikan lebih tinggi daripada yang dibelajarkan dengan pembelajaran konvensional $(54,37 \pm 6,64)$. Hal ini dapat dilihat berdasarkan hasil analisis data dari rincian perbedaan keterampilan proses sains siswa, yakni: (1) terdapat perbedaan keterampilan proses sains siswa yang dibelajarkan dengan model pembelajaran problem based learning $\left(\mathrm{t}_{\text {hitung }}=11,120 ; \mathrm{P}=\right.$ 0,000 ). Dimana nilai pretes keterampilan proses sains siswa pada problem based learning diperoleh 42,08 $\pm 9,16$ ), sedangkan nilai postes keterampilan proses sains siswapada problem based learningdiperoleh $64,27 \pm 7,46$; (2) terdapat perbedaan keterampilan proses sains siswa yang dibelajarkan dengan pembelajaran konvensional ( $\mathrm{t}_{\text {hitung }}=9,623 ; \mathrm{P}=0,000$ ). Dimana nilai pretes keterampilan proses sains siswapadapembelajaran konvensionaldiperoleh $40,41 \pm 9,38$, sedangkan nilai postes keterampilan proses sains siswa pada pembelajaran konvensional diperoleh 54,37 \pm 6,64. Perbedaan keterampilan proses sains siswa pada materi ekosistem yang dibelajarkan dengan model pembelajaran Problem Based Learningdan pembelajaran konvensionaldi SMP Swasta Silinda Serdang Bedagaitersaji pada Gambar 1. 


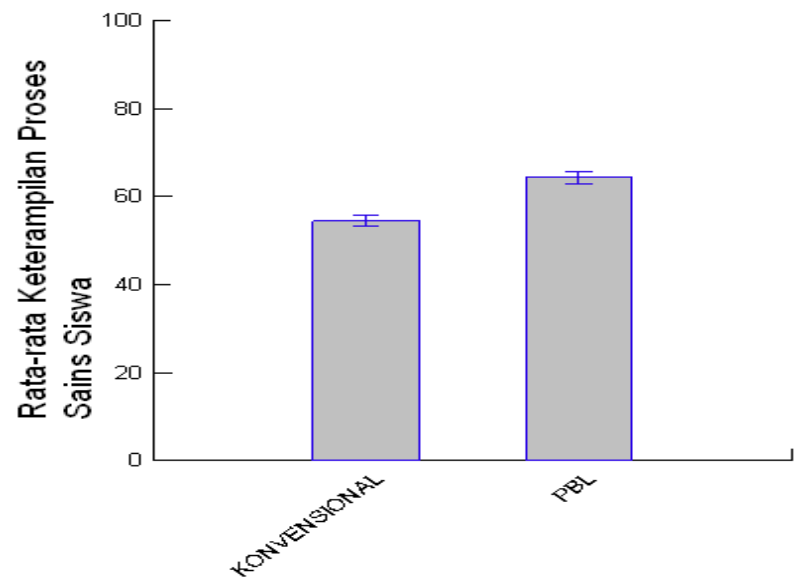

Gambar 1. Perbedaan Keterampilan Proses Sains Siswa pada Materi Ekosistem yang Dibelajarkan dengan Model Pembelajaran Problem Based Learning dan Pembelajaran KonvensionalDi SMP Swasta Silinda Serdang Bedagai

\section{Pengaruh Model Pembelajaran (Problem Based Learning, dan Konvensional) Terhadap Hasil Belajar Siswa Sekolah Menengah Pertama}

Berdasarkanhasil uji hipotesis diperoleh bahwaterdapat pengaruh model pembelajaran (Problem Based Learning, dan konvensional) terhadap hasil belajar siswa pada materi ekosistemSMP Swasta Silinda Serdang Bedagai $\left(\mathrm{t}_{\text {hitung }}=3,342 ; \mathrm{P}=0,001\right)$. Hal ini dapat dilihat pada hasil belajar siswa pada materi ekosistem yang dibelajarkan dengan model pembelajaran Problem Based Learning (74,25 5,87) signifikan lebih tinggi daripada yang dibelajarkan dengan pembelajaran konvensional $(67,66 \pm 9,04)$.

Hal ini dapat dilihat berdasarkan hasil analisis data dari rincian perbedaan hasil belajar siswa, yakni: (1) terdapat perbedaan hasil belajar siswa yang dibelajarkan dengan model pembelajaran problem based learning ( $\mathrm{t}_{\text {hitung }}=$ $12,826 ; \mathrm{P}=0,000)$. Dimana nilai pretes siswa pada problem based learning diperoleh $48,41 \pm$ 8,47 ), sedangkan nilai postes siswa pada problem based learning diperoleh 74,25 $\pm 5,87$; (2) terdapat perbedaan hasil belajar siswa yang dibelajarkan dengan pembelajaran konvensional $\left(\mathrm{t}_{\text {hitung }}=6,695 ; \mathrm{P}=0,000\right)$. Dimana nilai pretes siswa pada pembelajaran konvensional diperoleh 48,75 $\pm 9,84$, sedangkan nilai postes siswa pada pembelajaran konvensional diperoleh 67,66 \pm 9,04.Perbedaan hasil belajar siswa pada materi ekosistem yang dibelajarkan dengan model pembelajaran Problem Based Learningdan pembelajaran konvensionaldi SMP Swasta Silinda Serdang Bedagai tersaji pada Gambar 2.

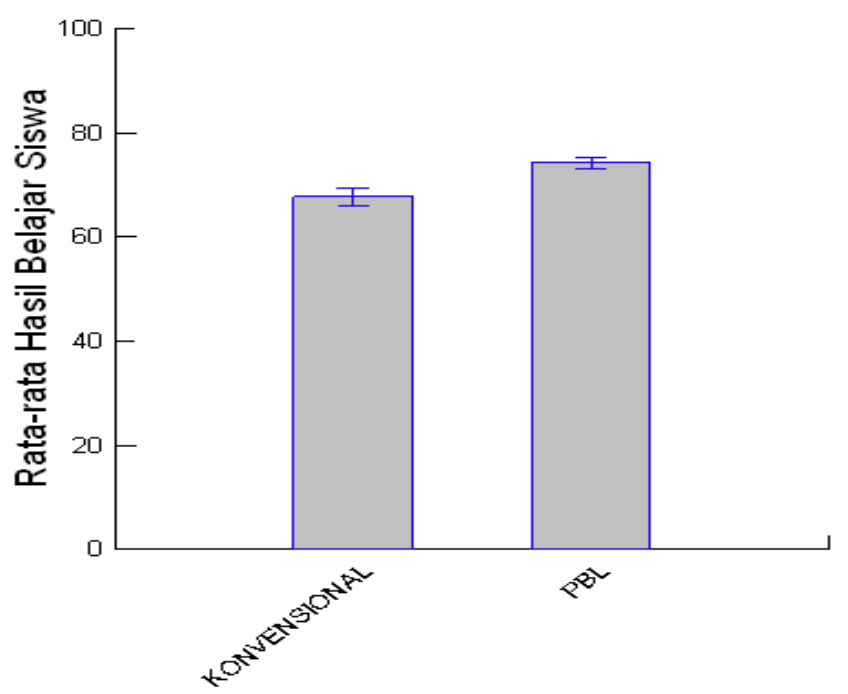

Gambar 2. Perbedaan Hasil Belajar Siswa pada Materi Ekosistem yang Dibelajarkan dengan Model Pembelajaran Problem Based Learning dan Pembelajaran KonvensionalDi SMP Swasta Silinda Serdang Bedagai 


\section{PEMBAHASAN}

Pengaruh Model Pembelajaran (Problem Based Learning, dan Konvensional) Terhadap Keterampilan Proses Sains Siswa

Pada hasil penelitian ini diperoleh bahwaketerampilan proses sains siswa pada materi ekosistem yang dibelajarkan dengan model pembelajaran Problem Based Learning $(64,27 \pm 7,46)$ signifikan lebih tinggi daripada yang dibelajarkan dengan pembelajaran konvensional $(54,37 \pm 6,64)$ sebesar $18,20 \%$. Hal ini disebabkan karenaProblem based learning merupakan pembelajaran berdasarkan masalah, dimana siswa menyelidiki dan menuntaskan dengan mencari solusi masalah biologi sesuai kehidupan nyata. Oleh sebab itu model problem based learning merupakan pembelajaran dengan pendekatan konstruktivis, dimana guru memberikan informasi sebanyakbanyaknya kepada siswa. Dalam problem based learning siswa mengerjakan permasalahan yang otentik dengan maksud untuk menyusun pengetahuan mereka sendiri, mengembangkan pengetahuan dan keterampilan berpikir siswa serta mengembangkan kemandirian dan kepercayaan diri siswa itu sendiri. Sebagaimana dikemukakan oleh Nasution (2008) bahwa pada proses problem based learningGuru berperan sebagai penyaji, penanya, pengadaan dialog, pemberi fasilitas kegiatan pembelajaran, menyiapkan dukungan dan dorongan yang dapat meningkatkan pertumbuhan intelektual siswa di dalam kelas. Sehingga pada prinsipnyaproblem based learning melakukan pendekatan secara kontruktivis yakni pengetahuan tidak diterima secara pasif oleh siswa, melainkan dibangun secara aktif oleh individu siswa itu sendiri.

Proses pembelajaran problem based learning memotivasi siswa dalam mengembangkan kemampuan pemecahan masalah dengan cara memecahkan satu masalah spesifik dan memahami materi yang terkait dan menjadikan murid menjadi mandiri melalui keterampilan proses sains siswa. Pada problem based learningsiswa dapat mengembangkanketerampilan proses sains dengan menerapkan metode ilmiah dalam memahami, mengembangkan dan menemukan ilmu pengetahuan pada kasus pemecahan masalah mengenai materi ekosistem.

Dengan keterampilan proses sains, siswa dapat mengembangkan sains serta memperoleh pengetahuan baru dan mengembangkan pengetahuan yang telah diperolehnya tersebut (Dahar,2011).Sehingga tugas guru pada proses pembelajaran problem based learning adalah membantu dan membimbing siswa melakukan keterampilan proses sainsnya.Dengan keterampilan proses sains, siswa berinteraksi dengan sesamanya dalam melaksanakan kegiatan belajar mengajar, misalnya mendiskusikan hasil pengamatan pada materi ekosistem dan solusi pemecahan masalahnya.

Melalui proses pembelajaran problem based learning, keterampilan proses siswa dapat meningkat seiring dengan siswa mencari pemecahan masalah secara otentik melalui metode ilmiah dalam mengembangkan sains, yakni: memahami konsep dari materi biologi dengan baik dan benar, mengembangkan pengetahuan yang telah dimiliki sebelumnya dengan menyesuaikan perkembangan penemuan dan ilmu pengetahuan yang baru. Sehingga siswa dapat menemukan ilmu pengetahuan yang baru pula dalam dirinya. Semiawan (1992) menyatakan bahwa ada empat alasan mengapa pendekatan keterampilan proses sains sangat baik diterapkan dalam proses belajar mengajar sehari-hari di dalam kelas, yaitu: (1) perkembangan ilmu pengetahuan dan teknologi berlangsung semakin cepat sehingga tidak mungkin lagi guru mengajarkan semua konsep dan fakta pada siswa; (2) adanya kecenderungan bahwa siswa lebih memahami konsep-konsep yang rumit dan abstrak jika disertai dengan contoh yang konkret; (3) penemuan dan perkembangan ilmu pengetahuan dan teknologi tidak bersifat mutlak $100 \%$, tapi bersifat relatif; dan (4) dalam proses belajar mengajar, pengembangan konsep tidak terlepas dari pengembangan sikap dan nilai dalam diri anak didik.Dengan demikian pada proses pembelajaran problem based learning, siswa dapat membangun kontruktivis pengetahuannya melalui pembelajaran berbasis masalah, yang secara otentik siswa memperolehdan mengembangkan suatu gagasan mengenai materi ekosistem tidak hanya selalu mengandalkan guru melainkan dari diri siswa dalam membangun gagasan dan pengetahuannya sendiri melalui konsep dan sikap ilmiah yang benar melalui keterampilan proses sains siswa.

\section{Pengaruh Model Pembelajaran (Problem Based Learning, dan Konvensional) Terhadap Hasil Belajar Siswa}

Pada hasil penelitian ini diperoleh bahwa hasil belajar siswa pada materi ekosistem yang dibelajarkan dengan model pembelajaran Problem Based Learning (74,25 5 5,87) signifikan lebih tinggi daripada yang 
dibelajarkan dengan pembelajaran konvensional $(67,66 \pm 9,04)$ sebesar $9,73 \%$. Hal ini dikarenakan pada model problem based learning merupakan pembelajaran dengan pendekatan konstruktivis yang berbasis masalah secara otentik menginstruksikan pengalamanpengalaman baru kepadasiswa untuk mendasarkan diri dan memodifikasi pengetahuan yang sebelumnya dimiliki oleh siswa.

Dalam penggunaan pembelajaran Problem Based Learning penting bagi siswa memiliki pemahaman awal yang baik terkait materi yang diajarkan untuk memecahkan masalah yang diajukan oleh guru, dan mengasah kemampuan siswa dalam berpikir kritis dalam menganalisis permasalahan yang ada. Sebagaimana dikemukakan oleh Dewey (dalam Arends, 2008) bahwa Problem based learning merupakan pembelajaran berdasarkan masalah, dan mendeskripsikan pandangan tentang pendidikan sekolah sebagai cermin masyarakat yang lebih besar dan pembelajaran di dalam kelas akan menjadi laboratorium untuk penyelidikan dan penuntasan masalah kehidupan nyata.

Esensi problem based learning berupa penyuguhan berbagai situasi bermasalah yang autentik dan bermakna kepada siswa, yang dapat berfungsi sebagai batu loncatan untuk investigasi dan penyelidikan (Arends, 2008). Dimana masalah-masalah yang dikemukakan dalam problem based learning ini akan efektif jika masalah itu jernih, konkret, dan dekat dengan keseharian siswa (Afcariono, 2008). Oleh sebab itu pada proses pembelajaran problem based learning, guru berperan sebagai penyaji, penanya, pengadaan dialog, pemberi fasilitas penelitian, menyiapkan dukungan dan dorongan yang dapat meningkatkan pertumbuhan intelektual peserta didik serta dapat meningkatkan hasil belajar siswa menjadi lebih baik.Melalui penggunaan model pembelajaran problem based learning maka akan memberikan hasil belajar yang baik pula. Hasil belajar tersebut dapat berupa kemampuan, keterampilan dan sikap siswa dalam melakukan dan menyelesaikan suatu masalah/ hal setelah ia menerima pengalaman belajarnya melalui problem based learning. Dengan demikian problem based learning dapat memberikan pengaruh terhadap hasil belajar siswa, sehingga guru dapat mengetahui apakah proses belajar mengajar yang telah dilakukannyatelah dapat mencapai tujuan pembelajaran. Oleh sebab itu pilihan para guru atas model-model pembelajaran harus memperhatikan dan mempertimbangkan kesesuaian kondisi dalam menerapkannya untuk mendapatkan hasil belajar yang lebih baik untuk kedepannya.

\section{KESIMPULAN}

Hasil penelitian ini memberikan kesimpulan bahwa: (1)terdapat pengaruh model pembelajaran (Problem Based Learning, dan konvensional) terhadap keterampilan proses sains siswa pada materi ekosistemSMP Swasta Silinda Serdang Bedagai; dan (2) terdapat pengaruh model pembelajaran (Problem Based Learning, dan konvensional) terhadap hasil belajar siswa pada materi ekosistemSMP Swasta Silinda Serdang Bedagai.

\section{DAFTAR PUSTAKA}

Abdurrahman dan Bintaoro. 2000. Belajar dan Mengajar. Jakarta: Rineka Cipta.

Afcariono, Muhammad. 2008. Penerapan Pembelajaran Berbasis Masalah untuk Meningkatkan Kemampuan Berpikir Kritis Siswa pada Mata Pelajaran Biologi. Jurnal Pendidikan Inovatif. Vol 3.

Ango, M, L. 2002. Mastery of Science Process Skills and Their Effective Use in the Teaching of Science: An Educology of Science Education in the Nigerian Context. International Journal of Educology. Volume 16 No 1.

Arends, Richard, I. 2008. Learning to Teach. Belajar untuk Mengajar. Edisi Dua. Yogyakarta: Pustaka Pelajar.

Arikunto, S. 2003. Prosedur Penelitian. Jakarta: Rineka Cipta.

Arikunto, S. 2006. Prosedur Penelitian (Suatu Pendekatan Praktik Edisi Revisi VI). Jakarta: Rineka Cipta.

Arsyad, A. 2007. Media Pembelajaran. Jakarta: Raja Grafindo Persada.

Bloom, B, S. 1956. Taxonomy of Educational Objective: Hand Book I: Cognitive Domain. New York.

Cahyadi, F.D. Suciati, Probosari, R.M. 2012. Penerapan Blanded Learning dalam Pembelajaran Biologi untuk meningkatkan Kemampuan Berpikir Kritis Siswa Kelas XI IPA 4 Putra SMA RSBI Pondok Pesantren Modern Islam Assalam Sukoharjo Tahun Pembelajaran 2011/2012. Jurnal Pendidikan Biologi. Vol 4.

Dahar, RW. 2011. Teori-Teori Belajar dan Pembelajaran. Jakarta: Erlangga.

Daryanto. 2009. Panduan Proses Pembelajaran Kreatif dan Inovatif. Jakarta: AV Publisher.

Dimyati dan Mudjiono. 1999. Belajar dan Pembelajaran.Jakarta: Rineka Cipta.

Djiwandono, S, E, W. 2002. Psikologi Pendidikan. Edisi revisi. Jakarta: Grasindo.

Hamalik, O. 2008. Kurikulum dan Pembelajaran. Jakarta: Bumi Aksara. 
$\begin{array}{cccc}\text { Hilman. 2011. Revisi } & \text { Taksonomi } & \text { Bloom. } \\ \text { Perpustakaan } & \text { Pasca } & \text { Sarjana } & \text { UNP. }\end{array}$ (http://hilman.web.id, diakses 15 Desember 2015).

Iabordo dan Gaikwad. 2005. Group Investigation: How Does It Works?. InFo. 8:79-98.

Karamustafaoglu, S. 2011. Improving the Science Process Skills Ability of Science Student Teachers Using I Diagrams. Eurasian Journal of Physics and Chemistry Education. Volume: 3, Issue: $1, \mathrm{p} 26-38$

Nasution, S. 2008. Berbagai Pendekatan dalam Proses Belajar dan Mengajar. Jakarta: Bumi Aksara.

Sari, I, M. 2012. Taksonomi Tujuan Pendidikan Menurut Bloom. (http://file.upi.edu, diakses 15 Desember 2015).

Semiawan, C, R. 1992. Pengembangan Kurikulum Berdifferensiasi. Jakarta: Grasindo.
Sudirman. 1992. Ilmu Pendidikan. Bandung: Remaja Rosdakarya.

Sudjana, N. \& Rivai A. 2002. Media Pengajaran. Bandung: Sinar Baru Algensindo.

Sukmadinata, S. 2008. Pengembangan Kurikulum Teori dan Praktek. Bandung: Remaja Rosdakarya.

Syamsuri, I. 2004. Sains Biologi SMP Untuk Kelas VII. Jakarta: Erlangga.

Trianto. 2007. Mendesign Model Pembelajaran Inovatif dan Progresif. Jakarta: Kencana.

Trianto. 2010. Model Pembelajaran Terpadu: konsep, Startegi, dan Implementasinya dalam Kurikulum Tingkat Satuan Pendidikan (KTSP). Jakarta: Bumi Aksara.

Winarsih, dkk. 2008. IPA Terpadu SMP Kelas VII. Jakarta: Pusat Perbukuan, Departemen Pendidikan Nasional. 